\title{
TRANSFORMATIVE CONSTITUTIONALISM: SEPARATE BUT EQUAL? A SCEPTICAL APPROACH
}

\author{
by Ruan du Toit*
}

'The horizon of rights is as limitless as the hopes and expectations of humanity.' - Sachs $\mathrm{J}^{1}$

\section{Transformative constitutionalism}

There is no single coherent definition of transformative constitutionalism. ${ }^{2}$ However, in keeping with the spirit of transformation as set about in the Constitution of the Republic of South Africa (Constitution) some common ground must be ascertained as to the notion of what transformative constitutionalism is. It is quite fair to contend that the Constitution ${ }^{3}$ seeks to heal the wounds of the past. ${ }^{4}$ In doing so, the Constitution ${ }^{5}$ endorses substantive equality rather than formal equality. ${ }^{6}$ The focus shifts toward an equal outcome in a given situation, relative to the unique circumstances in our society, and not a blanket provision blindly setting out means to achieve equality. Former Chief Justice Langa refers to this phenomenon of transformative constitutionalism as a social and economic revolution. ${ }^{7}$ Our Constitutional Court has, as it often does, painted in broad strokes a notion of the ideology of transformative constitutionalism: 8

Ours is a transformative constitution ... Our Constitution provides a mandate, a framework and to some extent a blueprint for the transformation of our society from its racist and unequal past to a society in which all can live with dignity.

From these broad strokes and ideological notions, one can identify the object of transformative constitutionalism in a post-apartheid South African society: a truly equal society, where all decisions must be substantiated by law. ${ }^{9}$

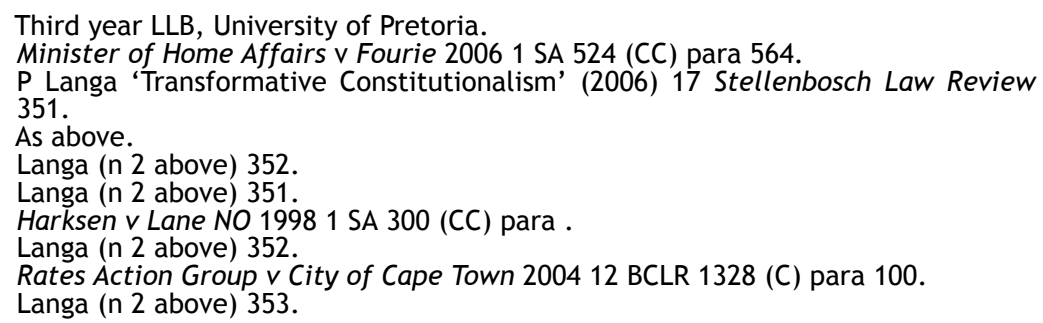


I dare say that I call it, however laudable, a sentimental notion. Van Marle utilises an expression that I treasure - the 'spectacle of post-apartheid transformative constitutionalism'. ${ }^{10}$ She elucidates the fact that if our society cannot acknowledge the limits of the law and human rights, we are doomed to rediscover the ordinary and transformative constitutionalism will have very little or no effect on the ordinary everyday lives of human beings. ${ }^{11}$ If our Constitution ${ }^{12}$ does not have the power to change ordinary lives, it has failed in its objective of transforming our post-apartheid South African society. We must therefore be critical and even sceptic, of our Constitution ${ }^{13}$ and the pedestal upon which human rights is resting. Klare has suggested that a post-liberal reading of our constitution is the correct approach in reading the provisions and values set about therein, for the very reason that it is a post-liberal constitution embodying the most advanced of rights, such as socio economic rights. ${ }^{14}$

A rather curious case resurfaces regarding a post-liberal reading of the Constitution, where the majority of the Constitutional Court (I would most humbly contend) failed to apply the correct reading of the Constitution ${ }^{15}$ and created a backdoor for the legislature to formally discriminate against a category of persons.

What case would my bleeding liberal hart then, as a friend often so kindly phrases it, be aggrieved about? The one atop the shrine of annoyance to many religious and more conservative members of our post-apartheid society:

\section{Minister of Home Affairs v Fourie $e^{16}$}

I believe the lone dissenter in the matter, former Justice O'Regan, applied the correct reading of section 39(2) of the Constitution by using the so-called principle of 'reading in' to create a gender-neutral definition of marriage in the Constitution.

Section 39(2) of the Constitution requires a court to promote the 'spirit, purport and objects' of the Bill of Rights when interpreting legislation or developing the common law. Former Justice O'Regan was in lone dissent regarding the appropriate remedy pertaining to the unconstitutionality of the definition of marriage in the Marriage Act. ${ }^{17}$ She would have had the order with immediate effect and alter

14 KE Klare 'Legal culture and transformative constitutionalism' (1998) South African Journal of Human Rights 146-188.

15 Langa (n 2 above) 351.

16 Fourie (n 1 above).

1725 of 1961. 
the common law definition of marriage, traditionally being the lifelong union of one man and one woman to the exclusion of all others while it lasts, be gender neutral by utilising the so-called principle of 'reading in'. ${ }^{18}$

Instead, the majority of the court gave the legislature time to correct the definition of marriage, and formally discriminate against lesbian, gay, bisexual and transgender persons. The legislature enacted the Civil Union Act. ${ }^{19}$

Under the Civil Union Act, ${ }^{20}$ spouses can elect to have their union known as a marriage or a civil union. ${ }^{21}$ I employ the phrase 'formally discriminate', because for the most part the Civil Union $\mathrm{Act}^{22}$ brings about the same consequences as the Marriage Act. ${ }^{23}$ There however seems to lurk some sense of inferiority in the air about a civil union. Generally, albeit a somewhat anecdotal claim (but has nonetheless become a finding of fact in American law), ${ }^{24}$ society does not regard a civil union as a marriage.

The question arising can be concisely formulated as follows: although a civil union can be registered as a marriage under section 12(3) of the Civil Union Act, ${ }^{25}$ does such registration give rise to the same cultural and traditional symbolic values associated with that of marriage?

\section{The long and winding road}

Coincidentally, a Beatles song by the name of 'The long and winding road ${ }^{26}$ popped into my mind as I deliberated what the next heading in this article might be. It is a rather appropriate metaphor for the road lying ahead regarding transformative constitutionalism, and judicial review. A very wise man that has taught me interpretation of statutes not too long ago, impressed the following upon my mind: very few things in life are final. ${ }^{27}$

In the Fourie case, ${ }^{28}$ the Court emphasised marriage's 'congenial symbolic dimensions as a normative good to which access must be encouraged'. ${ }^{29}$ Yarbrough suggests a consolidationist approach to the

18 See National Coalition of Gay and Lesbian Equality $v$ Minister of Home Affairs 20002 SA 1 (CC) and CJ Botha, Statutory interpretation: An introduction for students (2005) 38.

17 of 2006.

As above.

Sec 12(3).

n 19 above.

n 17 above.

See In re Marriage Cases ( 42 below) and Perry $v$ Schwarzenegger ( $\mathrm{n} 44$ below). n 19 above.

The Beatles 'The long and winding road' from the album Let it be (1970).

Professor CJ Botha.

n 11 above. 
situation in South African matrimonial law. ${ }^{30}$ The author emphasises the harm of symbolic exclusion ${ }^{31}$ in a multicultural post-apartheid society. It would appear that the ideal solution is for the legislature to consolidate the Marriage Act, ${ }^{32}$ Recognition of Customary Marriages $\mathrm{Act}^{33}$ and Civil Union $\mathrm{Act}^{34}$ in a single comprehensive package of family legislation. It would be most ideal for co-habitation relationships lacking official recognition to be addressed in the consolidated marriage legislation as well.

One might speculate that internal cabinet strife could have caused the proliferation of marriage legislation, and has consequently diverted the rail of progress onto the tracks of "separate but equal' 35 in our post-apartheid society.

It would be most fanciful to believe the legislature will consolidate marriage legislation any time soon in the foreseeable future. We have here to do with a category of persons who by all means are entitled to measures of substantive equality pertaining to marriage, but their human dignity, equality and freedom ${ }^{36}$ as fundamental values are undermined by avoiding formal equality. Justice Edwin Cameron elucidates that there has never been a good time to be gay in modern Western society. ${ }^{37}$ I believe we merely have a somewhat more tolerant yet hostile relationship with people living in same-sex unions, or persons who are merely effeminate males or emasculate females. It may even be said that there is a frail and toxic atmosphere of bare tolerance in society towards such persons. We have a golden thread of double standards running through society. What is to be done then? Judicial review. At face value, this might seem ludicrous. Judicial review of what? Proliferated marriage legislation? Yes.

\section{A comparative perspective: it is possible}

In South Africa, the so-called equality provision in the Bill of Rights strongly entrenches the right not to be discriminated against on grounds of sexual orientation. ${ }^{38}$ Mindful of that, my attention had been brought to curious legal proceedings in the United States of

MW Yarbrough 'South Africa's wedding jitters: consolidation, abolition or proliferation’ (2006) 18 Yale Journal of Law and Feminism 498.

Yarbrough (n 29 above) 498.

Yarbrough (n 29 above) 498.

n 13 above.

n 17 above.

n 19 above.

Yarbrough (n 29 above) 506.

Sec $1(a)$ of the Constitution.

E Cameron 'Sexual orientation and the law' (1992) South African Human Rights Yearbook 87.

Sec 9 of the Constitution. 
America. The twitter sphere was buzzing, or we should rather say tweeting - live from the courtroom about the matter throughout the most of 2010.

In the State of California, same-sex marriage had been banned by a constitutional amendment to the State Constitution limiting marriage as a union between only a man and a woman. ${ }^{39}$ This had been done in accordance with electorate law, by means of a statewide referendum called Proposition 8. 40 The state-wide initiative succeeded by the skin of its nose, in a $52 \%$ yes and a $48 \%$ no vote. The State of California has given adequate recognition to domestic partnerships and same-sex co-habitation in terms of the California Family Code since 1998. ${ }^{41}$

The Supreme Court of California ruled domestic partnerships to be inferior to a marriage, although providing all the same material benefits of marriage, and a violation of the right to due process (In re Marriage Cases). ${ }^{42}$ After conservative family value groups were aggrieved by the decision, the initiative to amend the State Constitution had been brought about by Proposition 8. After an unsuccessful challenge in the State Supreme Court, the opponents of Proposition 8 took their battle to Federal Court, contending the State Constitution violated their Fourteenth Amendment right to due process under the Federal Constitution. ${ }^{43}$

\section{The lawfare in Perry $v$ Schwarzenegger 44}

\subsection{The factual matrix}

Miss Perry and Miss Stier, along with Mister Zarrillo and Mister Katami, two same-sex couples that desired to be joined in matrimony, but were subsequently denied marriage licenses on the basis of Proposition 8, sued the Governor (then Arnold Schwarzenegger) and

Proposition 8 amending the California Constitution §। and $\$ 7.5$ subsequently limiting the legal recognition of marriage to opposite-sex couples only.

$J$ Croyle 'Perry $v$ Schwarzenegger, Proposition 8 and the fight for same-sex marriage' (2011) 19 American Journal of Gender, Social Policy \& the Law 426.

Division 2 Part 1 \$297-297.5 defining a domestic partnership under California law and conferring upon domestic partners the same rights and responsibilities as married couples (as set out in the California Family Code \$308.5). For the sake of clarity, it is quite interesting to note that although codification is traditionally synonymous with the civil law, the State of California has a unique set of 29 Codes based on the English law. In essence, therefore, California law is a codified system of English law, and as such is quite an anomaly to the Anglo-American legal tradition (although based thereupon) which is not codified. See http:// www.leginfo.ca.gov/calaw.html (accessed 26 September 2011).

183 P 3d (Cal 2008) 384, 445.

United States Constitution 1789.

704 F Supp 2d (ND Cal 2010) 921, 927-928. 
several other California State officials in their official capacities. ${ }^{45}$ Chief Federal District Court Judge Vaughn Walker (since retired) overturned Proposition 8. The basis for his decision is founded upon the fact that the amendment to the State Constitution violated the opponents of Proposition 8's Fourteenth Amendment Federal Constitutional right to due process and equal protection, ${ }^{46}$ a twofold test in American constitutional law. The state had no legitimate interest in limiting marriage to opposite sex couples. One should be mindful to identify that the so-called anti-interference principle in American constitutional law comes into play, where the state may not interfere with individual liberties unless there is a legitimate governmental interest to do so. The 'rationality principle' was also deployed to conclude that the state had no rational basis for denying marriage licenses to same-sex couples. Despite a possible analogy between the so-called 'equality clause' in section 9 of the South African Constitution and the 'due process' clause of the Fourteenth Amendment to the United States Constitution, much of Perry's case ${ }^{47}$ is irrelevant to the post-apartheid South African context, save for two other crucial aspects.

These two key factors interplaying with South African constitutional law can be identified as follows: domestic partnerships, as civil unions, are inferior to marriages even though they provide all the same material benefits and recognition to same-sex couples as marriage provides for opposite sex couples. Secondly, marriage is a fundamental right. Based on the founding values set out in the South African Constitution: ${ }^{48}$ human dignity, equality and freedom, it can be acknowledged that there is a guarantee to the right of a person to marry the person of his or her choice, this choice encompasses the right to marry another person regardless of their gender. ${ }^{49}$

The basis for much of my argument is founded upon the following extrapolations of fact: in a jurisdiction where the right not to be discriminated against is so much more strongly entrenched ${ }^{50}$ than that of the United States when sexual orientation comes into play, why would a claim that civil unions are derogatory and denying a person the fundamental right to the traditional institution of marriage, rendering a category of persons second class citizens, not succeed?

n 35 above.

Amendment Fourteen to the United States Constitution 1789.

n 35 above.

n 28 above.

n 1 above.

n 39 above. 


\subsection{Marriage is a fundamental right}

The terra firma of the argument of the opponents of Proposition 8 in the Perry case ${ }^{51}$ was based upon the fact that marriage is a fundamental right. In the American context, marriage legislation banning interracial marriages has on often an occasion been overturned on constitutional grounds set about in the Fourteenth Amendment. 52

The Supreme Judicial Court of Massachusetts has succinctly illuminated the matter in its decision that banning same-sex marriage by state legislation is unconstitutional and a violation of the fundamental right to marry. In Goodridge $v$ Department of Public Health, ${ }^{53}$ the court held that withholding people from marriage is to bar them from participation in one of the state's most 'rewarding and cherished institutions,' and accordingly made no distinction between its traditional and same-sex variations in its analysis. ${ }^{54}$

In the South African context, marriage is a fundamental right. ${ }^{55}$ However, the proliferation of marriage legislation has created a category of second class citizens, so-called civil union partners. The state had no rational basis for not merely amending the definition of marriage in the Marriage Act ${ }^{56}$ as a gender-neutral definition. Section 36 of our Constitution, ${ }^{57}$ which is often referred to as the limitation clause, now interplays with the following factual matrix in our South African context. Is the proliferation of marriage legislation, which is a prima facie infringement of a fundamental right, reasonable and justifiable in an open and democratic society, based on human dignity, equality and freedom? ${ }^{58}$ Our Constitutional Court, in $S v$ Makwanyane, ${ }^{59}$ has endorsed a generous approach to interpreting rights with reference to the decision of the Supreme Court of Canada in $R \vee$ Big M Drug Mart. ${ }^{60}$

The substantive equality endorsement of our Constitutional Court as set about in Harksen $v$ Lane $N \mathrm{O}^{61}$ may however hamper this argument. A person is not owed formal equality over substantive equality. This argument has often times resonated in American

n 35 above.

Loving v Virginia 388 US 1, 10-11 (1967).

798 NE 2d 941, 949 (Mass. 2003).

$M$ van Camp 'Perry $v$ Schwarzenegger: A large step in the direction of marriage equality in California' (2011) Law \& Sexuality Review Lesbian Gay Bisexual \& Legal Issues 123.

n 40 above.

n 17 above.

n 12 above.

$\mathrm{Sec} 36(1)$ of the Constitution.

19953 SA 391 (CC).

(1985) 1 SCR 295.

19981 SA 300 (CC). 
constitutional law in a rather curios phrase: a person is not owed fairness over due process.

I believe, however, that the founding values embodied in our Constitution $^{62}$ should trump the substantive equality test when addressing marriage equality. I by no means suggest that substantive equality should be disregarded. It has a most vital role in transformative constitutionalism. A complex interplay of the human dignity, equality and freedom of a specific category of persons with whom the law has a long standing ill relationship, deserve consideration over substantive equality.

\subsection{Civil unions are not marriages}

It has already been reiterated in this paper that civil unions provide all the same material benefits to persons as marriage, and civil union partners can have their civil unions known as a marriage. ${ }^{63}$ However, the fundamental right to marry eludes civil union partners, and a sense of inferiority lurks about in the air. The position regarding civil unions in South Africa is very much ancillary to the position of domestic partnerships in the State of California at the time litigation proceedings in the Perry case ${ }^{64}$ began. In terms of California law, domestic partnerships provide all the same material benefits to domestic partners as a marriage. ${ }^{65}$ Judge Walker exposed the scenario in the Perry decision as such: 66

The availability of a domestic partnership does not provide gays and lesbians with a status equivalent to marriage because the cultural meaning of marriage and its associated benefits are intentionally withheld from same-sex couples in domestic partnerships.

The decision of Judge Walker is pending appeal from the Ninth Circuit Federal Court of Appeals, and the long term outcome of the decision is still somewhat precarious. ${ }^{67}$

The proliferation of marriage legislation in California is minute in comparison to South African matrimonial law. The provisions governing marriages and domestic partnerships in California are governed by two different parts of the Family Code. ${ }^{68}$ They are to be found in one and the same body of legislation. The domestic

62 n 39 above

63 Sec 12(3) Act 17 of 2006.

64 n 40 above.

65 California Family Code $\$ 297.5(\mathrm{~d})$ : 'The rights and obligations of registered domestic partners with respect to a child of either of them shall be the same as those of spouses.' Also see Elisa B v Superior Court 117 P3d (Cal 2005) 660, 670 where it was held that under the Uniform Parentage Act, a person may have two parents of the same sex in California.

$66704 \mathrm{~F}$ Supp 2d para 54.

67 Perry $v$ Schwarzenegger, No 10-16696 (9th Cir Aug 16, 2010).

68 n 53 above. 
partnership provision however does not provide domestic partners the option of having their partnership know as a marriage, as civil union partners in South Africa have. The South African law is nonetheless, still a proliferation of marriage legislation impeding the basic human rights of lesbians, gays, bisexuals and transgender persons to marry.

\section{Conclusion}

One might ask what more is necessary than adequate legal recognition of same-sex unions? We provide all the material benefits to such persons. The answer is unequivocal - human dignity. These categories of persons have had a prolonged suffering by means of victimisation and discrimination in the past and, in the spirit and purport of human rights, at the very least deserve to be beneficiaries of transformative constitutionalism. A complex myriad of factors come into play in a post-apartheid South African society when one approaches transformative constitutionalism. Conservative religious groups, the state, and victims of discrimination have competing interests. Ultimately the judiciary needs to protect constitutionally entrenched rights of minority groups when adjudicating such matters.

If an aggrieved party feels a civil union is not a marriage in the traditionally associated context thereof, and another aggrieved party perceives it an interest of his or hers to oppose such interest - the court has an obligation to protect the interest of minorities. If the approach of former Justice O'Regan had simply been followed in the Fourie case, ${ }^{69}$ there would not be any second class citizens being discriminated against under marriage legislation. Most respectfully said, instances arise where the judiciary needs to remove its gloves, and exceed its bounds where it is practical and necessary. If the legislature does not consolidate its marriage legislation, the judiciary should ideally respond by taking to the demeanour of: 'Then so be it, let us do it for you.'

My legal studies, and very particularly a course in Jurisprudence, have remoulded my mind in a rather eloquent manner. Emanating from a conservative background, the law has changed my perspective on the world and everyday life.

The problems in the world and the everyday life of every human being, in the de facto context thereof, cannot be resolved by the law. The law has limits. As soon as we can identify and acknowledge the limits of the law, we can purport to bring about change. In an ideal world, the law de jure is interwoven with the law de facto. Postapartheid South Africa is not Utopia. It is nonetheless not a reason for us not to strive thereto - and to better the everyday lives of human 
beings by acknowledging the limits of the law and human rights to bring about change.

To the person that may contend that my argument is outrageous or atrocious, I leave with the following quote of United States Supreme Court Justice Kennedy in Lawrence $v$ Texas: ${ }^{70}$ 'Our obligation is to define the liberty of all, not to mandate our own moral code.' 505 US 833, 850 (1992). 